\title{
THE GENUS CORYANTHES: A PARADIGM IN ECOLOGY
}

\author{
GÜNTER Gerlach
}

\author{
Botanischer Garten München-Nymphenburg, Menzinger Str. 65, D-80638 München, Germany \\ gerlach@extern.lrz-muenchen.de
}

AвSTRACT. Since Darwin, the pollination biology of Coryanthes has fascinated naturalists, but other aspects of its biology are equally interesting. Herman Crüger, Director of the Trinidad Botanical Gardens, first described the pollination process in 1864. He talked about the strong attraction of the floral scent to some kind of Hymenopteran, but the true nature of the reward was not discovered until 100 years later by Dodson and Vogel. Coryanthes species grow exclusively in so-called antgardens. These arboreal communities can reach diameters of $150 \mathrm{~cm}$ with the ant nest comprising $80 \mathrm{~cm}$. Both organisms share a destiny because the plant is condemned to death if the associated ant colony dies. The plants offer nectar in extrafloral nectaries and provide a framework for nest construction with their root system, while the ants defend the plants against herbivores and additionally fertilize them with vertebrate feces. This abundant provision of nutrients by the ants allows the plants to grow rapidly. Coryanthes plants raised artificially from seed require about 2 to 3 years to flower. This is perhaps one of the most rapid maturation times among orchids and is more remarkable because the flowers of Coryanthes species are large and massive. They can reach a weight of more than $100 \mathrm{~g}$, the most massive within the orchid family. Capsule ripening is also rapid; most species require only two months to mature a capsule containing around 600,000 seeds. This rapid maturation probably represents an adaptation to this vulnerable habitat. The pollination process is finely tuned with the attraction of one or a few species of male euglossine bees; no other type of insect can effect pollination. A bee that is too large for the passage between the epichile and column will die because it cannot escape the flower and seals the exit. A bee that is too small might pass without effecting pollination. This attraction of one or a few species of bee is the result of the specific preferences of the euglossine males to the chemical composition of the floral fragrance. The different species of Coryanthes have different scents, helping the taxonomist to delimit species that in nature are pollinated by the same bee in spite of color or form variations. All these peculiar ecological adaptations of Coryanthes are evolutionary solutions to survive extreme challenges. The ecology of these plants is so multifaceted that even after years of intense investigation they still hide some secrets.

Resumen. Desde la época de Darwin, la biología de polinización de Coryanthes fascinó a los naturalistas, pero no solo con este fenómeno este género sorprende a sus observadores. Dr. Crüger, el director del Jardín Botánico de Trinidad fue el primero que investigó el proceso de la polinización en 1864. Él habló de la intensa atracción del aroma floral a ciertos himenopteros, pero la verdadera recompensa buscada por las abejas fue descubierta hace tan sólo 100 años por Dodson y Vogel. Todas las especies de Coryanthes crecen únicamente en llamados jardines de hormigas, éstas comunidades pueden llegar a un tamaño de $150 \mathrm{~cm}$ de diametro, solo el nido de las hormigas mide unos $80 \mathrm{~cm}$. Los dos organismos son dependientes uno del otro, la planta esta condenada a la muerte si la colonia de hormigas asociada muere. Las plantas ofrecen nectar en nectarios extraflorales y con su sistema de raices facilitan una base para la construción del nido, mientras las hormigas defienden su planta contra herbívoros y las fertilizan con los excrementos de vertebrados colectados del suelo. La alimentación abundante permite a la planta un crecimiento muy rápido. Plantas de Coryanthes que crecen en viveros necesitan nada mas entre 2 a 3 años para florecer. Esto es tal vez es uno de los record en las orquídeas, porque las flores son muy grandes y pesadas. Estas pueden llegar a un peso de mas que 100 g, el cual es otro record dentro de la familia de las orquídeas. Las semillas para madurar necesitan solo 60 dias, una cápsula contiene alrededor de 600.000 granos de semilla, eso probablemente es una adaptación a su habitat tan vulnerable. El proceso de polinización es sincronisado con gran precision para atraer a una o pocas 
especies de euglosidos, solamente ellos pueden efectuar la polinización. Si una abeja demasiado grande para el pasaje de la flor es atraída, ella tapa la salida de la orquídea, resultando en la muerte de ambas. Una abeja demasiada pequeña puede pasar la flor sin efectuar la polinización. La atracción individualizada esta causada por la preferencia especifica de los machos de euglosidos en la composición química de los aromas florales. Las diferentes especies adentro del género Coryanthes tienen diferentes aromas florales, ayudando así también al taxónomo para distinguirlas o en otro caso unir especies variables cuales clones estan polinizados por la misma especie de abeja. Todas estas peculariedades de las especies de Coryanthes menciondas aquí son las respuestas de la evolución a la sobrevivencia en una ecología extrema. La ecología de estas plantas es tan compleja y diversificada que a pesar de un largo plazo de investigación intensiva, todavia no se conoce a cabalidad ó en totalidad una serie de procesos.

KeY wORDS: Orchidaceae, Coryanthes, ecology, pollination

From the beginning of cultivation of tropical orchids, plants of Coryanthes were in great demand by horticulturalists. This was mainly because of their bizarre flower morphology and the great difficulties in keeping them alive for more than a single flowering season. Even skilled growers found the cultivation of these plants a hard nut to crack. From the beginning of the 1970s some gardeners developed successful methods of cultivation for these fascinating plants. My story of Coryanthes and their biology started 30 years ago in the Botanical Garden of Heidelberg with my colleague, the famous orchid gardener Hans Gerhard Seeger. Together we were the first to assemble more than 30 species in the hot and humid greenhouse, and with our success the idea evolved to monograph the genus. I remember well when Cal Dodson encouraged me to work on this genus, because no one in the Neotropics could grow Coryanthes well for any length of time.

The genus Coryanthes was established by Hooker in 1831 and published in Curtis's Botanical Magazine together with a colored plate. Sixty-two names belonging to this genus have been published, but only 41 species are regarded here as valid. Only 14 valid species were published by different authors before 1980, so 27 species were described within the last 30 years. The scarcity of Coryanthes in herbaria has several possible explanations: 1) Plants are not frequent in the wild; 2) they are well protected by stinging ants; and 3) the flowers last for only two or three days. These factors result in infrequent collection of Coryanthes by botanists.

Plants of Coryanthes grow in humid lowland forests from sea level up to elevations of $1500 \mathrm{~m}$. They are frequently found along rivers and creeks; these habitats could reflect humid microclimates or they may simply represent a collection artefact caused by the easy accessibility from a dugout, the easiest way to travel in Amazonian lowland forest. Their geographical distribution ranges from Mexico (Veracruz, Coryanthes picturata Rchb.f.) to Bolivia (Cochabamba, Coryanthes vasquezii Dodson, Coryanthes macrantha Hook.), and Brazil (Espirito Santo, Coryanthes speciosa Hook. var. espiritosantense Ruschi).

Coryanthes species grow epiphytically in so-called ant-gardens (Fig. 1), which are the most complex and sophisticated of all mutualistic partnerships between ants and flowering plants. These gardens consist of masses of soil, detritus, and chewed plant parts assembled at the branches of trees, forming huge clumps that may reach diameters of around 80-100 $\mathrm{cm}$. All plant members in these partnerships are highly adapted, most of them obligate ant-garden plants. They are found in different plant families, e.g. Gesneriaceae (Codonanthe), Araceae (Anthurium), Cactaceae (Epiphyllum), Bromeliaceae (Aechmea), Piperaceae (Peperomia), Orchidaceae (Coryanthes, Epidendrum imatophyllum - obligate; Gongora, Sievekingia facultative). Most of them bear seeds with elaiosomes or arils that induce the ants to collect the seeds and place them in their nests. As the plants grow, nourished by the soil and other materials, their roots become part of the framework of the gardens. The ants in turn feed on the nectar offered in extrafloral nectaries and fruit pulp provided by the plants. The garden is strictly controlled by the ants; legitimate members are tended by the ants, but invaders to this favorable substrate are pruned by them. 


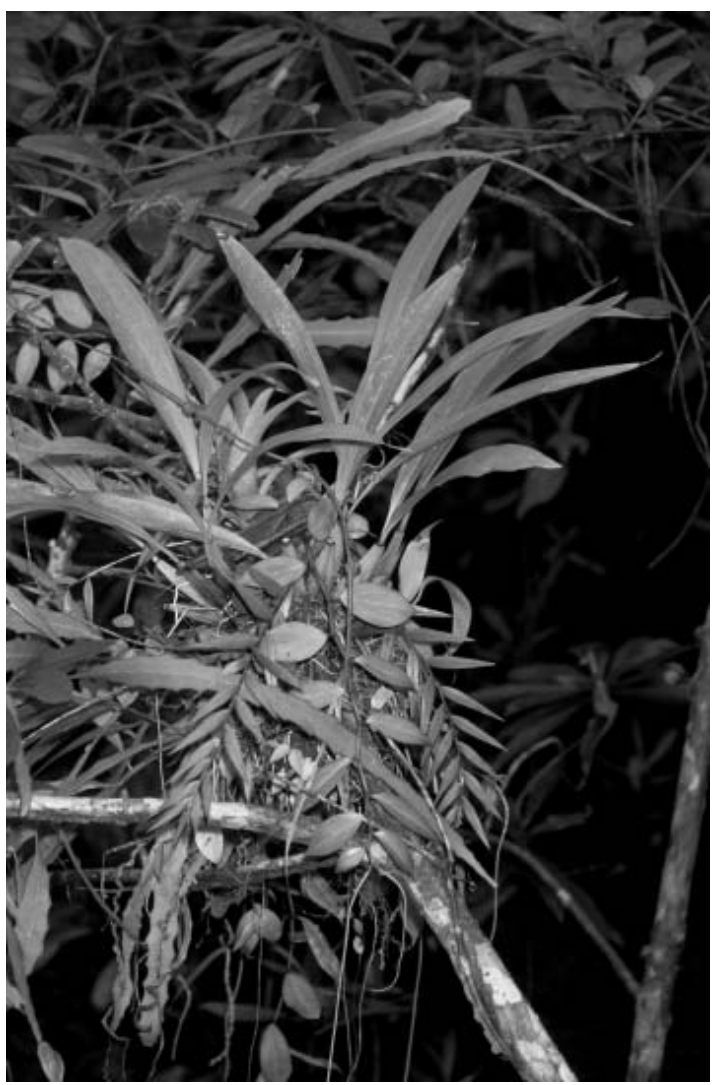

FIGURE 1. Ant-garden with Coryanthes flava, mangrove swamps of Mecana, Dept. Chocó, Colombia. The association consists of Epidendrum, Epiphyllum (Cactaceae), Peperomia (Piperaceae), Anthurium (Araceae), and some Bromeliaceae. (Photo: G. Gerlach)

In Coryanthes ant-gardens, the ants belong mainly to the genera Crematogaster, Azteca (Myrmicinae), and Camponotus (Dolichonderinae). The Coryanthes plant quickly develops an extensive root system that serves as a matrix for nest construction. Erect roots ('trash-basket roots') are often present; they collect leaf litter that decomposes around the plant, providing a constant flux of nutrients for the plant. Extrafloral nectaries occur on the plants' most vulnerable parts: new shoots, bracts, and the outer surfaces of the sepals when the flower still is in bud (Plate 1). The ants defend their sugar source against herbivores, maintain their garden, and fertilize their partners with vertebrate feces collected from the ground. Because of attentive cultivation by ants, Coryanthes species are rapid growers. If well provided with nutrients and the other requirements, an artificially raised Coryanthes can flower within $21 / 2$ years after sowing, a record within Orchidaceae keeping in mind that the flowers of this genus hold another record as the heaviest among orchids. The question in this mutualistic relationship is whether a Coryanthes seedling first colonizes an existing ant nest or the Coryanthes first establishes a root system that is subsequently colonized by the ants. Long internodes and small, scale-like leaves of seedlings sown asymbiotically in flasks support the hypothesis that the Coryanthes seed germinates deep in an ant nest and that the young seedling with its long internodes reaches the surface of the nest and then change its habit, developing the short internodes characteristic of the adult stage (Meyers and Lamb, 2009). Horich (personal communication) observed ants collecting seeds of an Epidendrum species growing in ant nests in Costa Rica. Dodson (cited by Benzing, 1984) argued that lipid deposits within Coryanthes seeds may also be attractive to ants, but to date this observation has not been confirmed nor refuted. So germination in the ant nest could be explainable but still needs to be investigated and confirmed. On the other hand, it is hard to imagine that the wind-dispersed balloon-seeds liberated by Schleuderhaare (hairs in the capsule that help to disperse seeds when the capsule opens) are collected and dispersed by ants. Has a second dispersal mechanism evolved? It is interesting to note that often trees carry more than one ant-garden with Coryanthes plants. In Guatopo National Park in Venezuela, we (G. Bergold, T. Graf, and I) found an huge mango (Mangifera indica L., Anacardiaceae) tree with more than 10 Coryanthes ant-gardens. How can the fact that all the ant nests were colonized by Coryanthes plants be explained? Many ants live in polygynous colonies or have extensions of their primary colony. So it is easy to imagine that ants collect Coryanthes seeds from a capsule opening in one of their ant-gardens and carry them to their extensions. Experiments to prove this hypothesis have not been undertaken; it is difficult to maintain a living ant-garden in cultivation. Even intact ant-gardens have not survived being moved, so these experiments have to be made in nature under difficult circumstances.

The genus Coryanthes is divided into two sections, C. sect. Coryanthes (previously C. sect. Eucoryanthes) with a smooth mesochile and $C$. sect. 
Plate 1. Extrafloral nectaries of Coryanthes rutkisii Foldats, indicated by arrows. Note that they are present on median vein of lateral sepals and median vein of bract. (Photos: G. Gerlach)

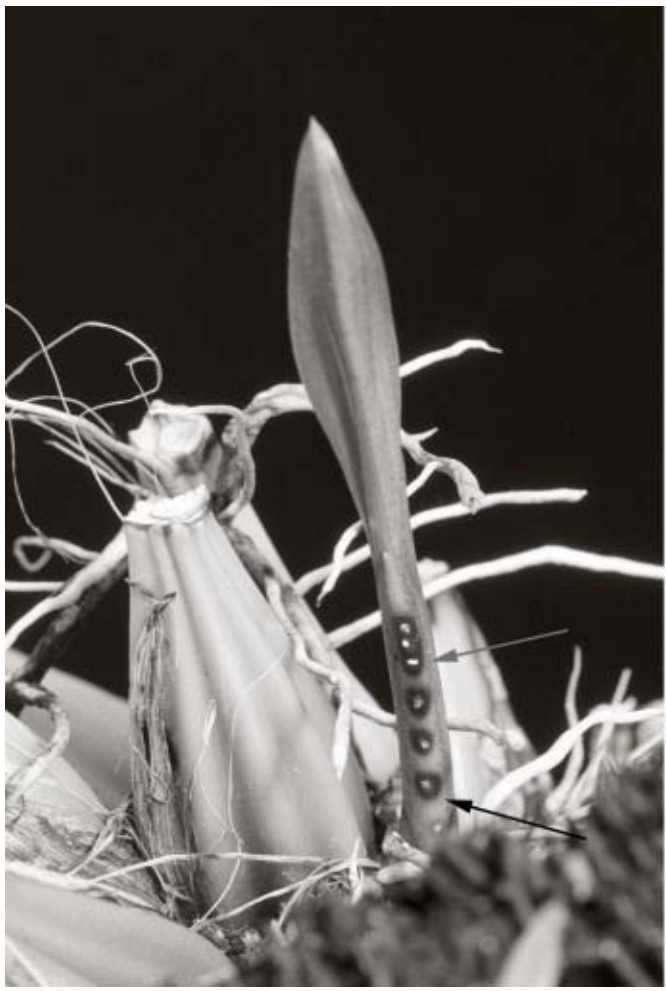

Lamellunguis with a mesochile bearing warts or lamellae. Micromorphology of the seeds (Plate 3) differs significantly between the sections. The seeds are all elongate, but those of $C$. sect. Coryanthes are fusiform, whereas those of $C$. sect. Lamellunguis have only one tapered side. Seed ripening is remarkably quick in Coryanthes species; most capsules need only 60 days to develop (Gerlach, 1993; Babczinsky et al., 2009). Similarly short times for seed ripening elsewhere in Stanhopeinae are found only in some species of Gongora, which occupy similar habitats. The other genera within this subtribe need more than six months to produce ripe seeds.

Molecular phylogenetic studies utilizing nrITS have not provided much resolution. However, they do support division into these two sections (Fig. 2), as well as a third clade composed of species with a nearly flat hypochile (versus semiglobose, cup-shaped), including the isolated species C. macrocorys Rolfe, the phylogenetic relationships of which were previously unclear. Erection of additional sections within the

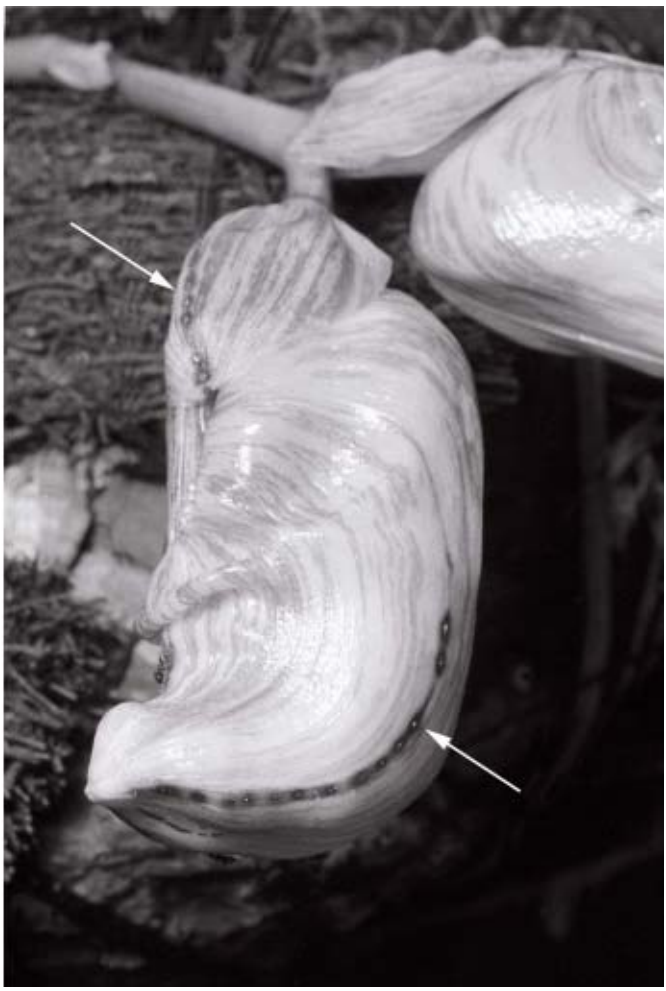

genus should await additional data that provide better resolution and support.

Coryanthes possess trap-flowers, with a spatial separation of anther and stigma that prevents selfpollination. Most non-orchid trap-flowers are proterogynous. In Aristolochia L. (Aristolochiaceae) species, for example, the flowers are first in the female phase, in which the pollinator enters the trap and leaves its pollen load at the stigma and cannot escape. On the following day the flowers switch to the male phase, releasing pollen onto the pollinator; the male and female phases are separated by time. Finally, the trap opens by wilting of the hairs that previously impeded the exit of the pollinators. In Coryanthes, however, the pollinator is forced to pass first by the stigma and then the anther; the separation of the sexes is here by space. From artificial pollinations we know that the stigma is receptive as soon as the flower opens.

Looking at the micromorphology of these trapflowers, one can detect several adaptations to keep the pollinators from escaping by flying or crawling out 


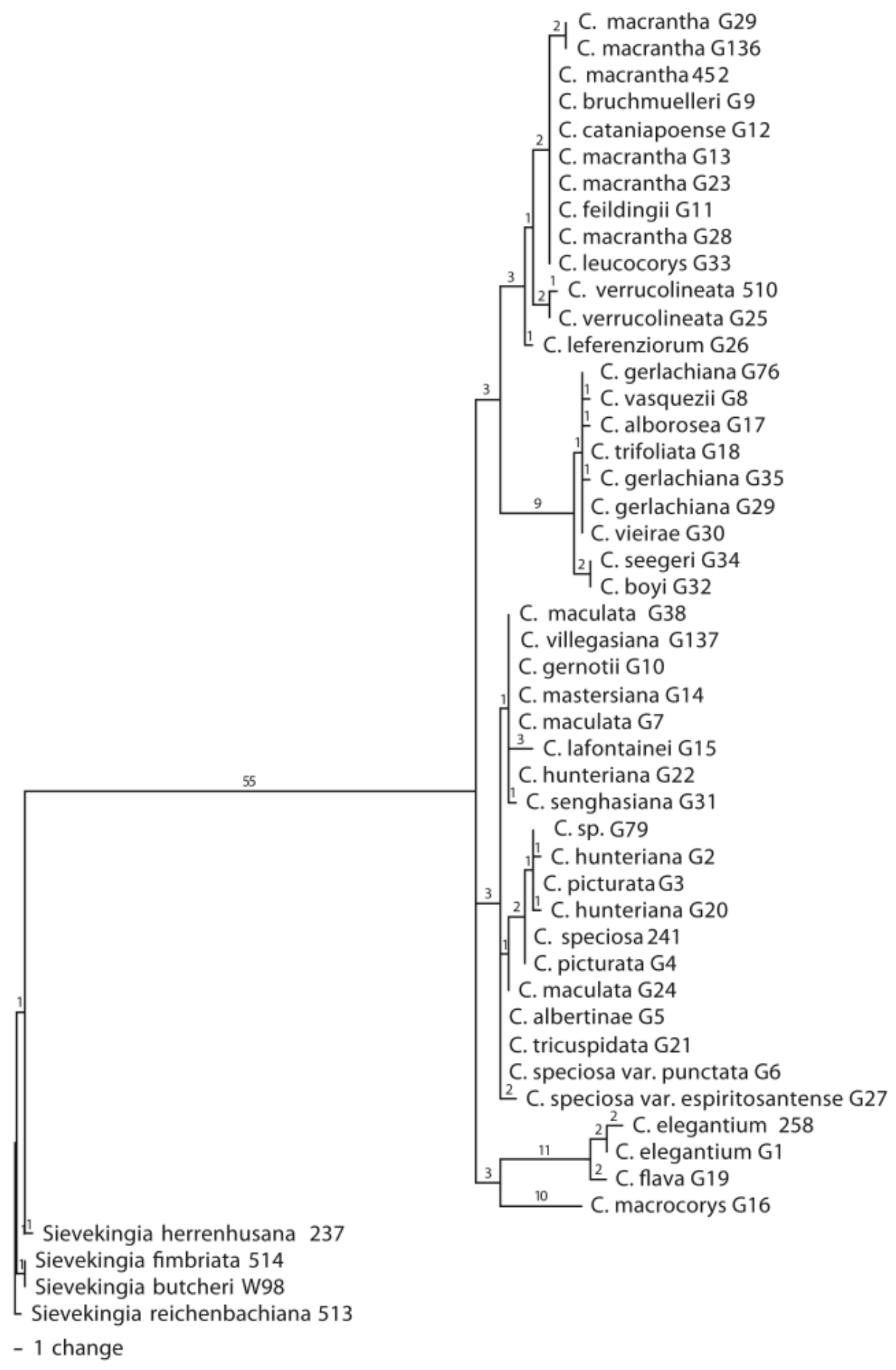

FIGURE 2. A single most-parsimonious tree from cladistic analyses of nrITS sequences of Coryanthes (Whitten and Gerlach, unpublished). Values above branches are number of steps. 
PLATE 2. SEM of surfaces of the flower of Coryanthes speciosa var. espiritosantense. (Photos: G. Gerlach).
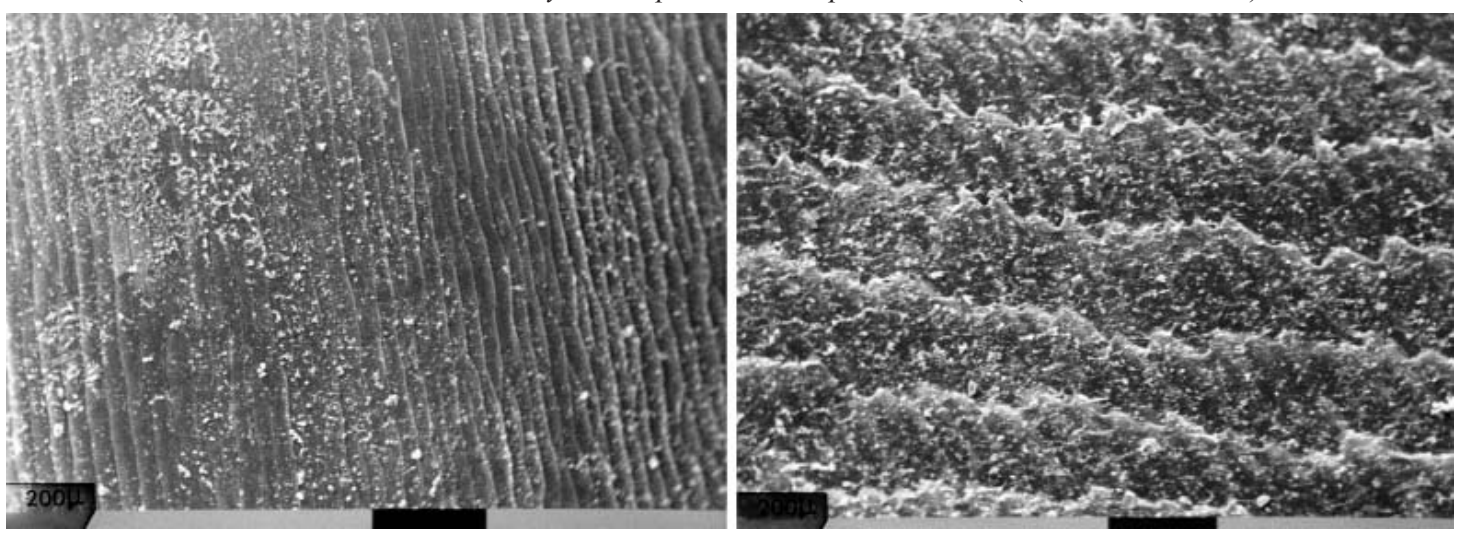

Plate 3. SEM of the seeds of Coryanthes. From left to right, upper row - C. sect. Lamellunguis: C. rutkisii Foldats, C. trifoliata; lower row - C. sect. Coryanthes: C. gernotii G.Gerlach \& Romero, C. albertinae (Photos: G. Gerlach).
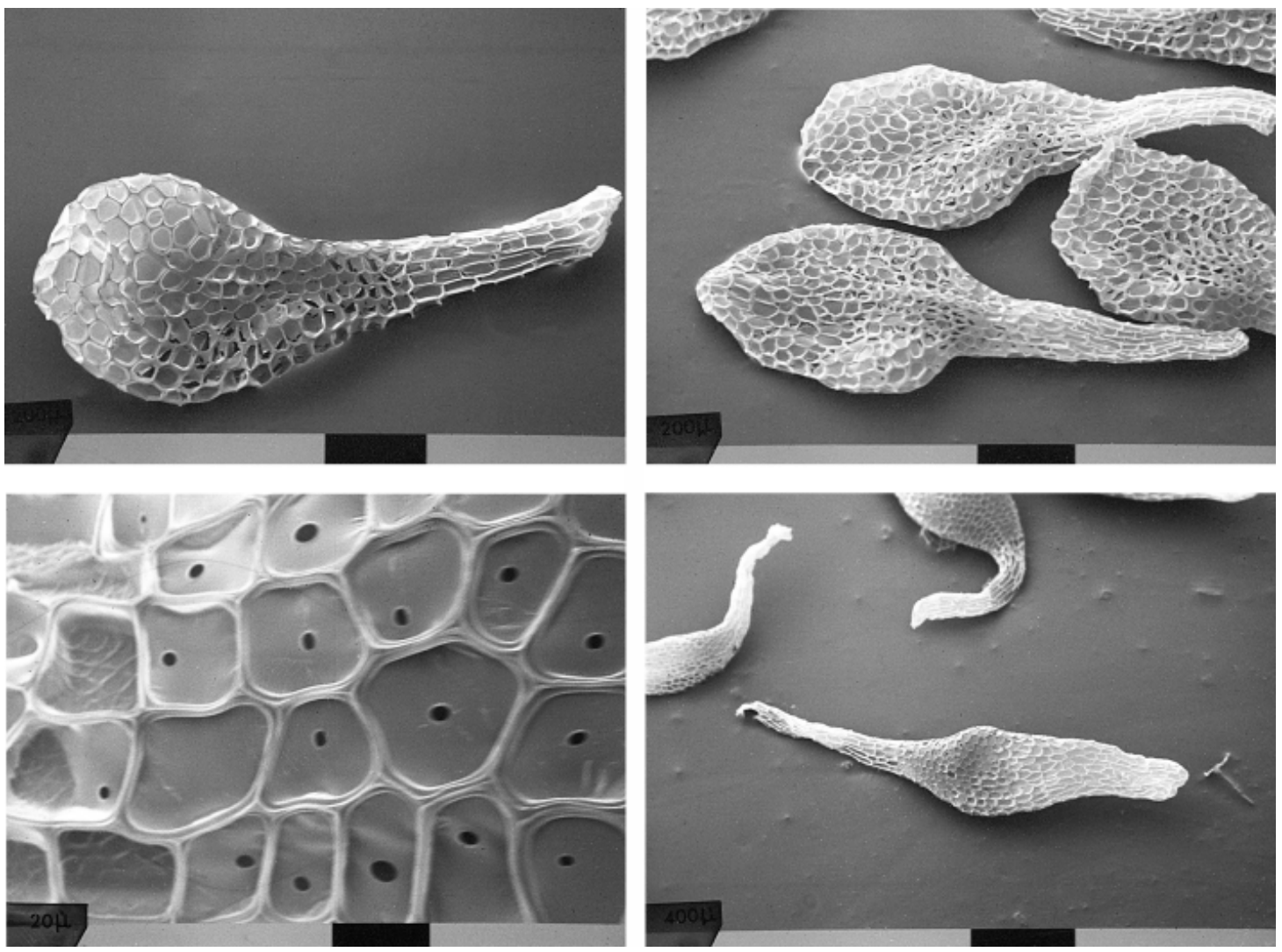

of the bucket (epichile). The pollinator is prevented from flying out of the bucket because its wings are wet from the liquid dripping from the basal glands and stored in the bucket. The liquid is not pure water (nor nectar) but contains some soap-like substance (saponins?) that disrupt surface tension of the liquid.

The walls of the bucket formed by the lip show cell arrangements similar to the carnivorous pitcher plants Cephalotus follicularis Labill. (Cephalotaceae) and Darlingtonia californica Torr. (Sarraceniaceae), which are not related to orchids (Barthlott and Ehler, 1977). The cells overlap a bit like roof tiles, and their surfaces 
Plate 4. Pollination of Coryanthes kaiseriana by Euglossa alleni in Costa Rica. From left to right: pollinator encompasses the midlobe of the epichile, trying to use his foreleg to pull himself out of the flower; pollinator nearly ready to escape the flower, the pollinarium now fixed on his body and the anther cap just before falling off; bee in recovery phase, in the drying process before leaving the flower. (Photos: G. Gerlach)
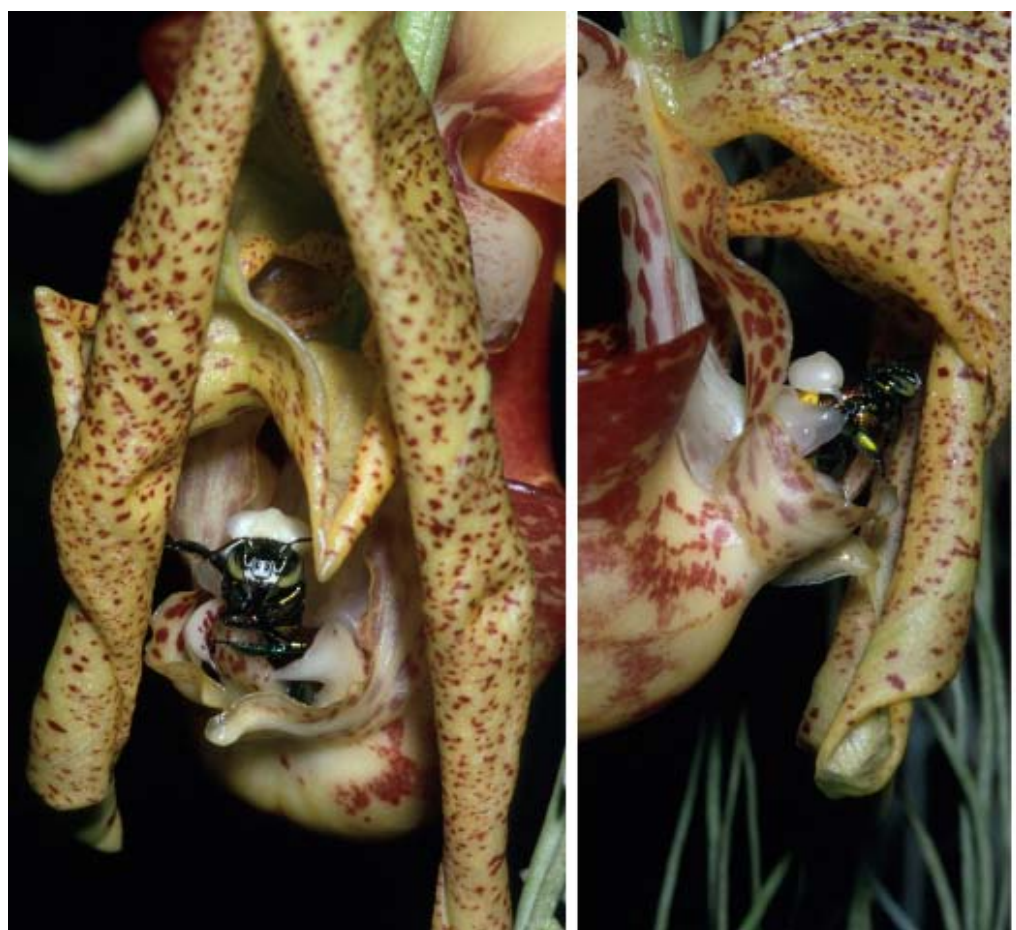

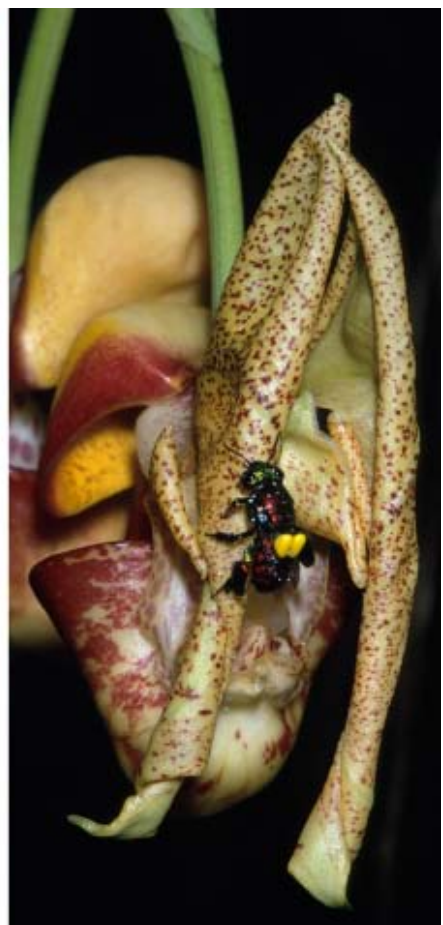

are covered by epicuticular waxes (Plate 2). These waxy, shingle-like surfaces are slippery, preventing the bees from climbing out of the bucket. The column also forms part of the trap; the cells lie side by side and also are covered by waxes.

Like all other Stanhopeinae, flowers of Coryanthes are pollinated by male, perfume- collecting euglossine bees. The floral fragrance is produced by osmophores hidden under the mostly cup-shaped hypochile of the lip. These volatile substances are both the attractant and reward for the bees. Each bee species has speciesspecific fragrance preferences that may also vary geographically and seasonally. In addition to orchid flowers, male euglossines collect volatiles from rotten wood or feces.

After collecting the fragrance compounds at the horn-shaped osmophore below the hood (hypochile) of the lip using its feathery, foretarsal brushes, the male euglossine bee hovers and transfers the accumulated chemicals to its hollow, inflated hind tibiae. Flying around with other individuals, eventually competing with them, the pollinator comes into contact with drops on the pleuridia (liquid-secreting glands at the base of the column) and falls in the liquid-filled bucket (epichile). From here the bee cannot escape because of the smooth surface of the inner side and its now-moistened wings. A lip callus at the level of the liquid provides a foothold and directs the bee towards the exit passageway formed by the tip of the lip and the column apex. The claw of the lip is flexible, enabling the bee to push the lip a little bit apart from the column, widening the exit so he can exit the bath. As he exits, he first passes the stigma. If he bears a pollinarium from a former visit, the bee presses the pollinia into the transverse stigmatic slit by its forward movement. The rostellum serves as a fork, catching the stipes and freeing the pollinia from the stipe and viscidium. As the bee struggles farther out the exit channel, the pollinarium is glued to the rear of his thorax. The pollinator struggles to get out of the flower, made more difficult by the slippery surfaces and lack of any structures that he can grasp with feet or mandibles (Plate 4). After successfully exiting the passage formed 


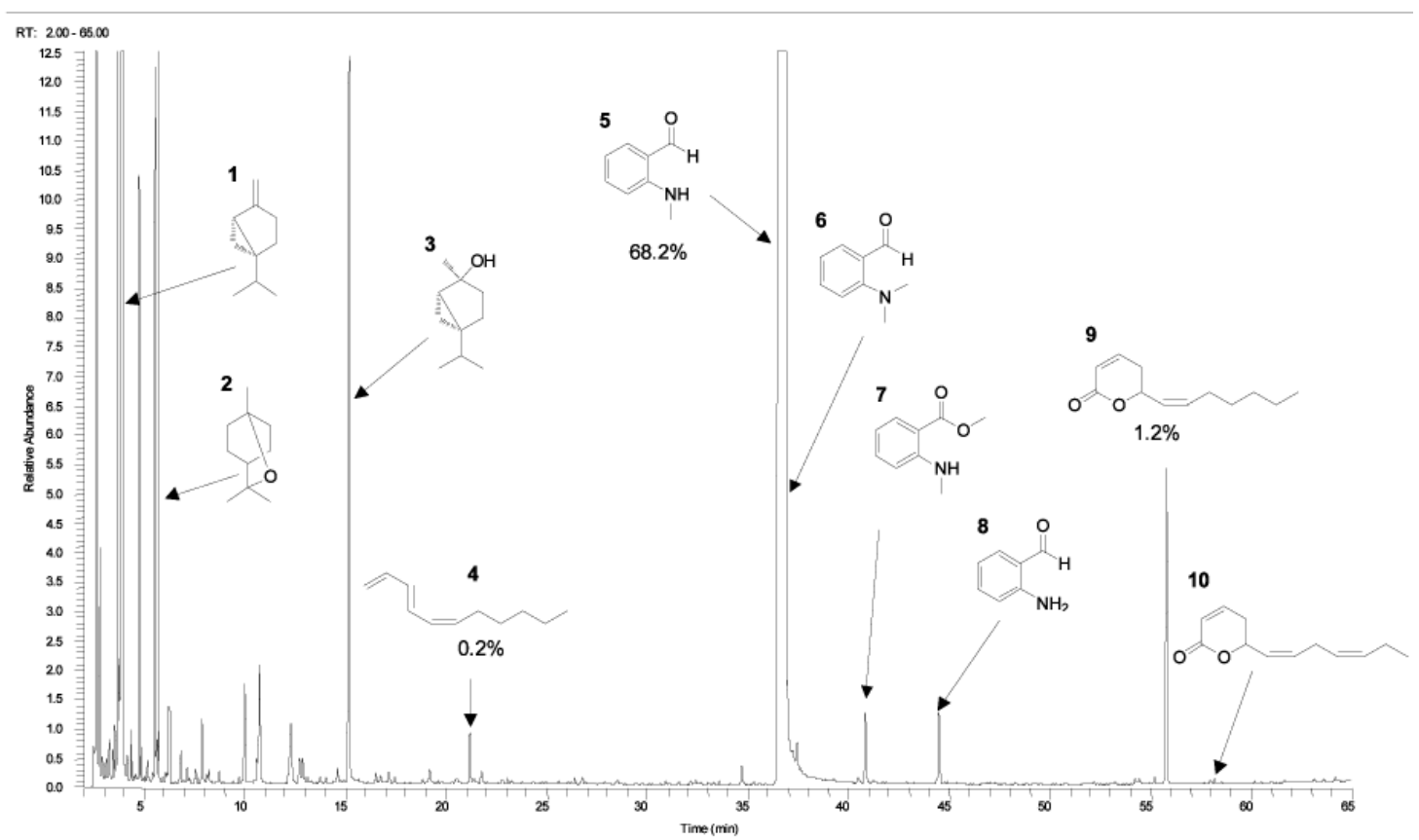

FigURE 3. GC/MS analysis of the trapped scent of Coryanthes kaiseriana: 1 - Sabinene; 2 - Eucalyptol; 3 - trans-Sabinene hydrate; 4 - (E,Z)-1,3,5-Undeca-1,3,5-triene; 5 - 2-(Methylamino)benzaldehyde; 6 - 2-(Dimethylamino) benzaldehyde; 7 - Methyl N-methylanthranilate;8 -2-Aminobenzaldehyde;9 -(Z)-Dodeca- 2,6-dieno-5-lactone;10 -(Z,Z)-Dodeca-2,6,9trieno-5-lactone. Courtesy of R. Kaiser (2006).

by lip and column, the bee remains on the flower for some time to dry itself. The entire pollination process lasts from 10 to 30 minutes depending on the presence or absence of the pollinarium.

Self-pollination is prevented by two mechanisms. First, the bee is probably traumatized by the bath and pollinarium placement and is less likely to revisit that same flower. Second, the fresh pollinia are too large to fit in the stigmatic slit and must dry for several minutes before they have shrunk enough to fit into the stigma.

The high degree of pollinator specificity mediated by floral fragrance composition may have several roles. First, it provides a reproductive isolating mechanism among sympatric species. Second, it reduces the number of bees of the wrong size from visiting the flower. This size specificity benefits both the bee and the orchid; if a bee too large for the exit canal is attracted and falls in the epichile, it cannot escape and dies in the flower, also preventing pollination. A bee too small for the flower can exit but does not effect pollination because it does not touch the stigma and pollinarium.
The floral fragrance of Coryanthes kaiseriana G.Gerlach (among other species) collected by the headspace technique includes two interesting chemical compounds (Fig. 3). 2-(methylamino)benzaldehyde (5) is a rare natural product, characterized by a peculiar dusty, leathery but still sweetish odor that is typical for C. mastersiana Lehm. (Gerlach \& Schill, 1989; Kaiser, 2006). This species grows in the lowland forests and mangrove swamps of the Chocó region to the Cauca valley in Colombia and in northern Ecuador. We have analyzed numerous individuals of this species. The color variation is enormous (Plate 5), but the fragrance composition shows a significant homogeneity. In all clones investigated the fragrance is highly dominated by 2-(methylamino)benzaldehyde showing concentrations from $80-99 \%$. Field studies carried out in Colombian Chocó near Bahia Solano with the synthetic product demonstrated the attractiveness of this substance to Euglossa chalybeata and Euglossa asarophora. Ten years after the discovery of this new natural product and five years after its description (Gerlach \& Schill, 1989), we finally collected bees by using this compound as 
Plate 5. Variability within Coryanthes mastersiana, all plants from Colombia, Dept. Chocó. Pictures not to scale. (Photos: G. Gerlach)

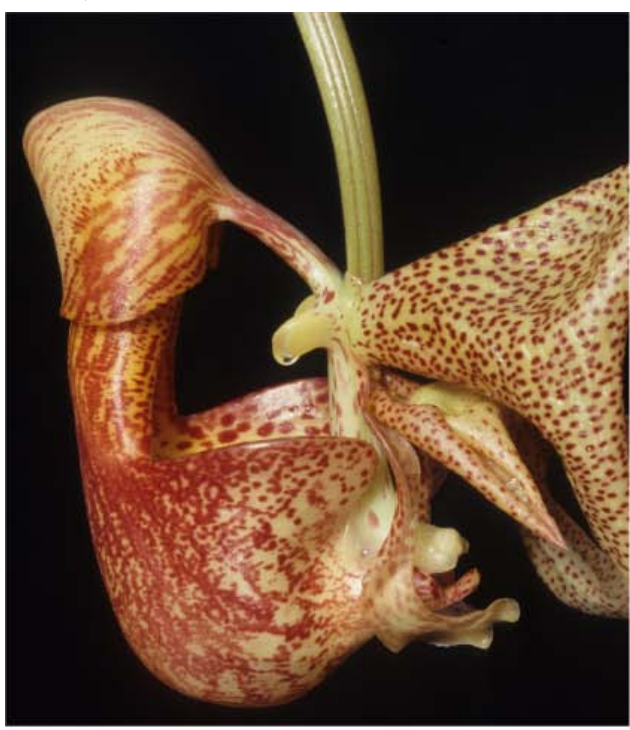

Coryanthes mastersiana Colombia, Dept. Chocó, Pacific Coast

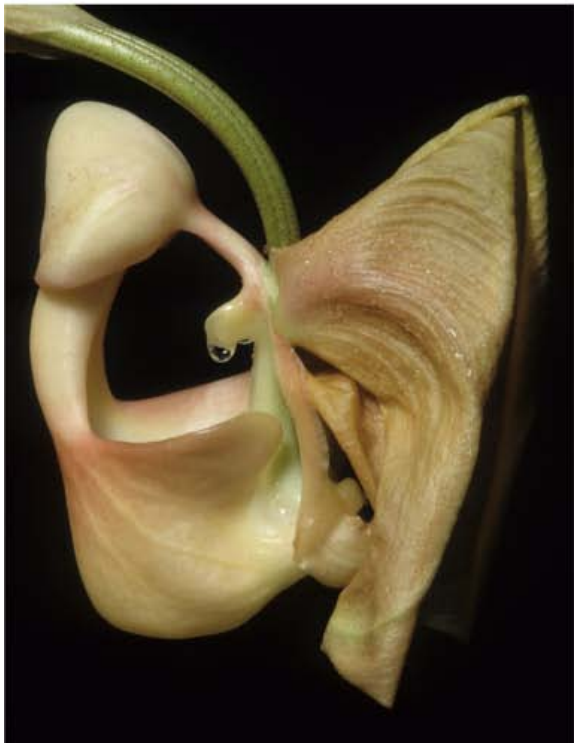

bait. Earlier attempts failed because we did not realize that this compound polymerizes easily, with resultant loss of activity. The substances 2-(dimethylamino) benzaldehyde (6), methyl N-methylanthranilate (7), and 2-aminobenzaldehyde (8) are produced in the same biosynthetic pathway but have not been tested as attractants.

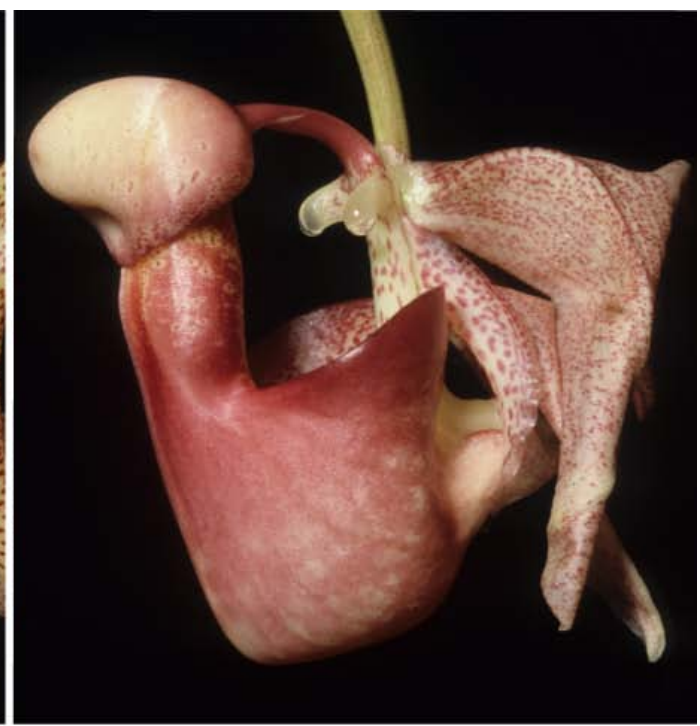

2-(Methylamino)benzaldehyde $\mathrm{NH}$

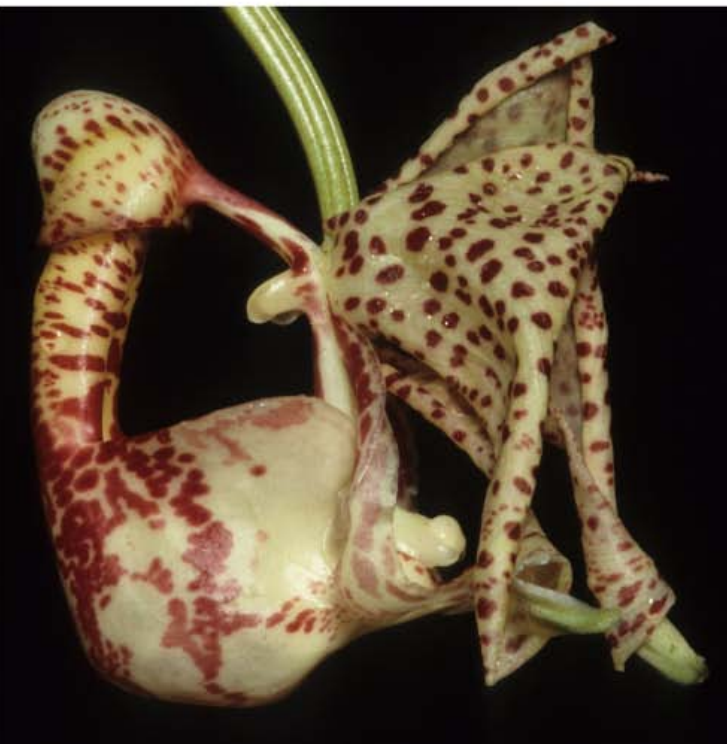

(E,Z)-1,3,5-Undeca-1,3,5-triene (4) is a highly fragrant representative of the other interesting group of chemicals in the fragrance of this Coryanthes species. This substance was found as a characteristic substance in the fragrance of $C$. albertinae Karsten from the Coastal Cordillera in Venezuela. Field tests in the habitat of that species with this synthetic alkene 
Plate 6. Different Stanhopeinae with ipsdienol as main substance; left above - Sievekingia butcheri; right above - Trevoria glumacea; middle - Gongora lagunae; left below -Stanhopea anfracta; right below - Coryanthes trifoliata. Pictures not to scale. (Photos: G. Gerlach)

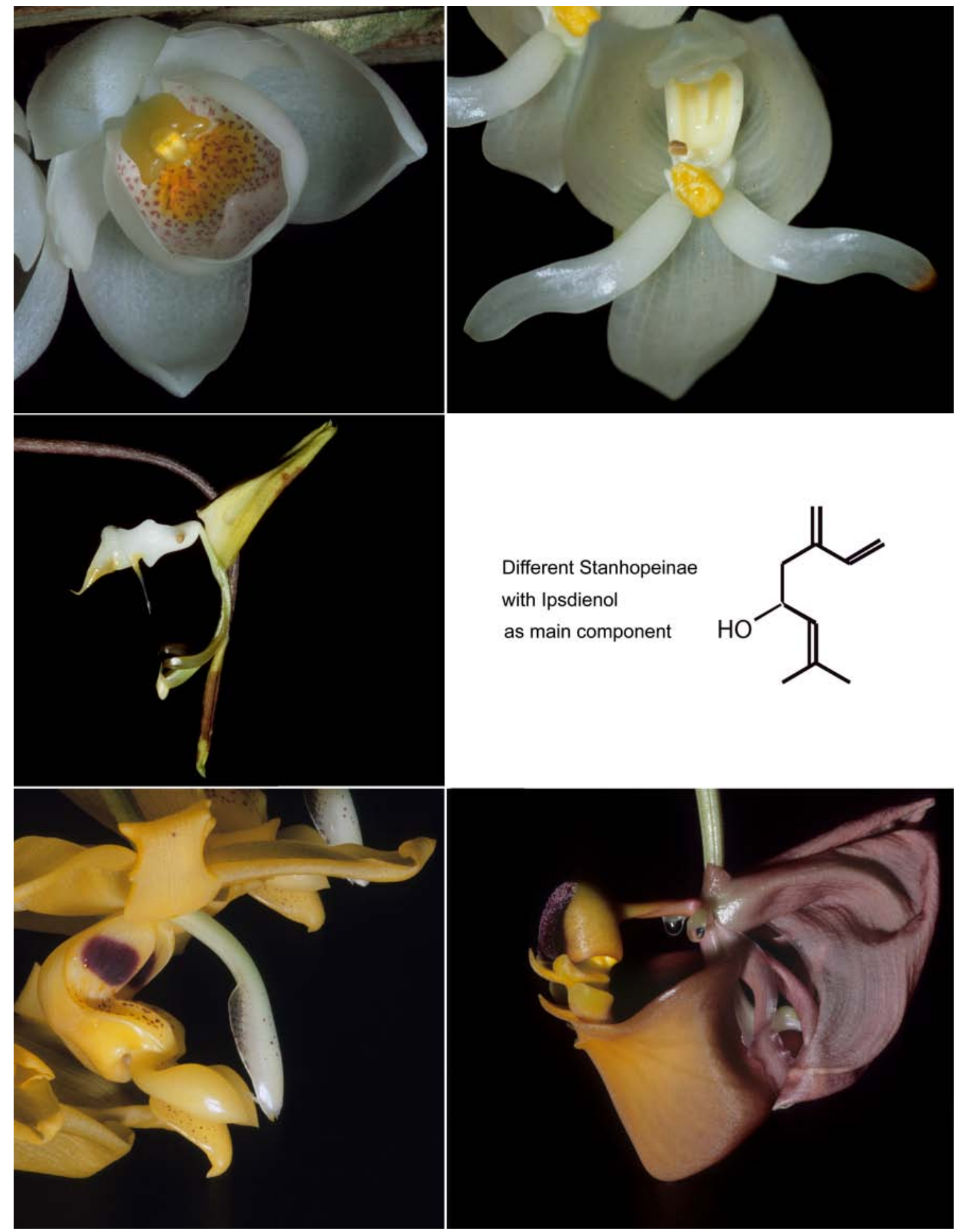


failed; the whole forest was filled with the aroma of green apple, characteristic of that chemical, but not a single euglossine bee was attracted. Two other baits on the same morning attracted 12 bees carrying pollinaria of $C$. albertinae. The failure was explained 10 years later when an oxygenated compound with a much longer retention time was found by Kaiser (2006) in the fragrance of $C$. albertinae. His team identified it as (Z)-Dodeca- 2,6-dieno-5-lactone (9). Field tests with this substance revealed an attractant that was the most powerful we ever tested. One drop offered to the bees in the field lasted for nearly a week even when the bait was exposed to tropical rain or full sunlight. This persistence is due to the low volatility of the lactone. By contrast, eucalyptol (2), used by most researchers baiting euglossine bees, volatilizes quickly and lasts only about an hour, depending on the air temperature.

Within Stanhopeinae, similar floral fragrance patterns may occur in different genera. Because of differing floral morphology, the different genera attach their pollinaria at different sites on the bee's body. These plants may attract the same euglossine bee species as pollinators without the risk of producing intergeneric hybrids (which are possible if produced artificially), even when they are growing in the same habitat. In the examples below, mechanical isolating mechanisms (pollinarium shape and placement) are critical, but floral fragrances are nearly identical among distantly related taxa. Ipsdienol with its precursor myrcene (see also Whitten et al., 1988) dominates the fragrance of Stanhopea anfracta Rolfe (40\%/25\%; ipsdienol/ myrcene ratio of total composition), Sievekingia butcheri Dressler (75\%/10\%), Gongora lagunae G.Gerlach (40\%/33\%), Trevoria glumacea Garay (49\%/16\%), and Coryanthes trifoliata C.Schweinf. $(51 \% / 32 \%$; Plate 6$)$. These species place pollinaria at different sites on the bees: legs (Sievekingia); legs of presumably the right-hand side (Trevoria, never observed!); below the scutellum directed toward the abdomen (Gongora, Stanhopea); and below the scutellum but directed toward the head (Coryanthes). Similarly, methyl salicylate (wintergreen oil) occurs as large percentages in fragrances of Houlletia lowiana (84-98\%), Stanhopea candida (55\%), and Coryanthes leucocorys (76-95\%), but each of these has distinctive pollinia attached in different locations or orientations on the bees.
I have touched only on the highlights of the interesting aspects of the ecology of Coryanthes. The different species are highly adapted to their habitats and consequently sensitive to human impacts on their environment. Protection of their natural habitats is the only way to conserve these strange plants. Hopefully, habitat conservation will ensure that our children will also be able to enjoy the study of Coryanthes in the wild.

ACKNOWLEDGMEnTs. My thanks go to Gerd Seeger, who encouraged me to work on this genus and established a good base with the collection of Coryanthes in the Botanical Garden of Heidelberg; Roman Kaiser, who performed the fragrance analyses; Mark Whitten, who carried out the molecular work, discussed Coryanthes, and improved my English; Alec Pridgeon for corrections and improvements on the text; Bert Klein and his team of gardeners in the plant collection; Jutta Babczinsky for technical assistance; DFG (German Research Foundation) for financial support during the field trips; and SYNTHESYS (Synthesis of Systematic Resources) and the European Union for an Integrated Infrastructure Initiative grant for financial support in herbarium research.

\section{LiterATURE CITED}

Babczinsky, J., G. Gerlach, B. Klein, V. Nazarov \& A. Richter. 2009. Published on the Internet; http://www. orchidsrepbiol.de/cgi-bin/RBO/seed_ripening/display. $\mathrm{pl} /$ accessed 2009.

Barthlott, W\& N.Ehler. 1977. Raster-Elektronenmikroskopie der Epidermis-Oberflächen von Spermatophyten. Trop. Subtrop. Pflanz. 19: 36.

Benzing, D. H. 1984. Epiphytic vegetation: a profile and suggestions for future inquiries. Pp. 155-171 in: E. Medina, H. A. Mooney \& C. Vasquez-Yánez (eds.). Physiological ecology of plants of the wet tropics. W. Junk, The Hague, The Netherlands.

Davidson, D. W. \& W. W. Epstein. 1989. Epiphytic associations with ants. Pp. 200-233 in: U. Lüttge (ed.). Vascular plants as epiphytes: evolution and ecophysiology.

Springer, New York.

Gerlach, G. \& R. L. Dressler. 2003. Stanhopeinae Mesoamericanae I. Lankesteriana 8: 23-30.

Gerlach, G. \& R. Schill. 1989. Fragrance analyses, an aid to taxonomic relationships of the genus Coryanthes (Orchidaceae). Pl. Syst. Evol. 168: 159-165.

Gerlach, G. \& R. Schill. 1993. Composition of orchid scents attracting euglossine bees. Bot. Acta 104: 379-391. 
Gerlach, G. \& R. Schill. 1993. Die Gattung Coryanthes Hook. (Orchidaceae): eine monographische Bearbeitung unter besonderer Berücksichtigung der Blütenduftstoffe. Trop. Subtrop. Pflanz. 83: 1-205.

Hooker, J. D. 1831. Coryanthes maculata. Curtis' Bot. Mag. 58: t. 3102.

Kaiser, R. 2006. Meaningful scents around the world. VHCA, Zürich, Switzerland.
Meyers, T. C. and Lamb, C. E. Published on the Internet; https://lab.troymeyers.com/flasking/article. php?about=Coryanthes-Seedlings/ accessed 2009.

Whitten, W. M., H. G. Hills \& N. H. Williams. 1988. Occurrence of ipsdienol in floralfragrances. Phytochem. 27: 2759-2760. 